\title{
Improving Students' Critical Thinking Ability through Learning Local History of Tanggomo with Contextual Teaching and Learning Approach at SMAN 03 Gorontalo
}

\author{
Djulia Indriani AH Mahmud ${ }^{1}$, Warto ${ }^{2}$, Sariyatun ${ }^{3}$ \\ ${ }_{1,2,3}$ Postgraduate Program in Historical Education, Faculty of Teacher Training and Education, Universitas \\ Sebelas Maret, Indonesia \\ djuliaindriyani@gmail.com
}

\begin{abstract}
This study aims to determine the relevance of local history learning to increasing critical thinking skills. Today's critical thinking skills have become the main ability students must have, but the history learning application which still tends to focus on improving students' cognitive by requiring students to memorize historical facts, makes students not have the opportunity to think critically. The lack of discussion of local history is also a problem in itself for learning history, even though local history can help students find meaning in learning history by examining events that are close to the student's environment. This study used a quasi-experimental method with a two-group pretest and posttest design. The results obtained indicate that historical learning that integrates local history using a contextual teaching and learning approach can improve students' critical thinking skills, this can be proven by the t test which was carried out by obtaining a significance of $0.00<0.05$, meaning that there is a significant and positive influence on history learning. local to improve students' critical thinking skills.
\end{abstract}

Keywords

local history learning; critical thinking ability; contextual teaching and learning

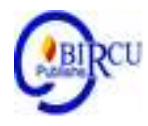

\section{Introduction}

Historical learning in its application still faces many fundamental problems, such as a lack of historical awareness, boring learning, and a lack of critical thinking skills in students. This low ability is thought to be caused by the implementation in history learning itself, where educators do not master the material, and in evaluating students tend to demand the same answer as the explanation, in the end students are not given the opportunity to think creatively and think critically. Learning local history is the study of the life of a particular community or community in the dynamic development of human life (Rosmiati, 2020). History learning also tends to prioritize students' cognitive abilities, forcing them to memorize hard facts in history, without giving meaning to events and helping students think chronologically, comparatively, creatively, and critically. Whereas critical thinking ability is a fundamental ability that students must have at this time.

According to Redecker, et al (2011: 21), critical thinking skills include the ability to access information, analyze, synthesize information, be trained, and mastered, in addition, aspects of critical thinking skills are very broad, and can be linked to communication skills. Added by Zubaidah (2016: 3), critical thinking skills are needed to improve students' ability to choose relevant sources and information, find quality sources, and assess sources from the aspects of objectivity, reliability, and updating. 
The 2013 curriculum demands lessons in schools including history lessons, with the aim of increasing critical thinking skills. Regulation of the Minister of National Education No. 22 of 2006, also states the importance of this ability, to train students' critical power to understand historical facts correctly based on a scientific approach and scientific methodology. Education plays a critical role in our lives and it is a bit blurry when to imagine what type of society we would have without education, and how we will function as individuals (Campbell-Phillips, 2020).

The ability to think critically is certainly very close to history learning, this is based on the history learning objectives contained in history learning, this ability is needed by students, because history learning emphasizes past events with the values contained therein, so that with this ability students will can analyze, reconstruct, evaluate, and synthesize an event, not only memorizing, but also giving meaning to the event.

In the process of learning history, students are expected to be able to think critically and be able to study an event, this is to minimize the level of boredom of students. It is said by Subakti (2010), learning history means students are able to think critically and are able to study every event that occurs in their environment, and can have an awareness of changes and values that are embedded in history learning. It is so important for every history teacher to note that learning history is very important. It is important not only to increase knowledge and insight in the field of history, but more broadly, students must be able to think critically, analytically, do assessment, and reason in every historical event that is studied.

Another problem in history learning that is no less important is the lack of discussion of local history, or history learning does not touch local elements. Whereas local history learning needs to be introduced to students to recognize their local identity and respect other ethnic or regional identities by considering the principles of learning and the stages of student development (Supardan, 2004: 262).

Abdullah (1990) also emphasized, "local history allows us to have a very intimate relationship with local events that may not be considered big, but actually have an important and valuable role in shaping bigger events (Wibowo, 2016: 47). From this statement it can be concluded that local history learning can be very meaningful and play a major role in the history learning process. Because teaching local history can bridge students in understanding a historical event in the surrounding community, local history can also be part of the formation of nation and character building for students that is not only aimed at national history.

Efforts to improve critical thinking skills can be actualized into history learning by incorporating local elements that store various events, traditions, and habits of local communities that can be used as historical sources. Critical thinking skills will be trained through local events by conducting study, analysis, synthesis, and reconstruction of historical sources.

Local history has contributed to the growth of positive values in students, the emergence of historical awareness, and the development of competence. This is supported by many studies that have found the same facts. Supardan (2004) states that the role of local history has provided identity and filled the vacuum, and has provided benefits to the development of a sense of belonging to the Indonesian nation (added Mulyana, Gunawan (2007)). That history learning which actualizes local history can improve critical thinking skills.

Efforts to increase competence, foster a love for history and culture, and hone skills, utilize local materials, need to be an alternative. Teachers can develop innovations in learning by including local history material while still referring to the national curriculum standards. 


\section{Review of Literatures}

\subsection{Critical Thinking Ability}

Johnson concluded that critical thinking is the ability to express opinion, by organizing and systematically evaluating personal opinions and the opinions of others (Johnson, 2006: 183). Menurt Priyadi (2005) critical thinking ability is a mental process for analyzing or evaluating information. This information can be obtained from observations, common sense or communication (Ariyati. 2010: 3). Furthermore, to improve critical thinking skills, according to Ennis, it is adjusted to the right criteria, where in general this capability has criteria, such as logical, critical, and pragmatic (Ennis: 1962). To achieve the objectives of this government regulation, schools must create a good learning system by following a predetermined curriculum (Rizqi, 2020).

Bailin, Sharon \& Siegel, Harvey (2002) added that the ability to think critically is the first and foremost ability in a variety of good thinking. Byer (1995), states that critical thinking means making reasonable judgments. According to Zubaidah (2010), critical thinking skills are the abilities used to understand concepts, apply, synthesize, and evaluate information obtained or generated. confirmed by King, et al (2010), who convey critical thinking skills, which are skills to carry out various analyzes, evaluations, and reconstructions that lead to rational and logical actions against various sources of information.

Kneedler in Costa (985) suggests critical thinking steps which are grouped into three aspects, where these aspects have their respective indicators, namely; first, or recognize the problem, which consists of; 1) identifying the main issues or problems; 2) comparing similarities and differences; 3) select the relevant information; 4) formulate and focus the problem. Second, assessing relevant information, consisting of; 1) selecting facts, opinions, and logical results; 2) check consistency; 3) identify assumptions; 4) recognizing possible stereotypical factors; 5) identify possible biases, emotions, propaganda, and misinterpretation of sentences. Third, solving problems, and drawing conclusions, consisting of; 1) identifying the required data and whether the data is sufficient or not; 2) predict the possible consequences of decisions or problem solving and the conclusions drawn (Zubaidah, 2010: 10).

Based on the above definitions, it can be concluded that the ability to think critically is the ability to provide reasoning, assessment, and analysis of information. Regarding the ability to think critically in history learning, this ability is clearly needed. According to Britt (1994), historical learning is not only limited to studying or recognizing an event, but also being able to unravel the threads of events scientifically. Learning history means students are able to think critically and be able to study any changes in their environment, and have an awareness of changes and the values contained in every historical event.

\subsection{Local History Learning}

Local history is a scope that studies and discusses small communities, places, and institutions, so that the objects of local history are very close to people's lives in one community (Broke. 2008: 1). According to Langbein \& Lichtman (1978), an important point of mutual concern regarding local history is the unique identity and solidarity possessed by local communities, so that in local history we will find the spirit and strength that was born from the collectivity of local communities.

Mulyana, \& Gunawan (2007) added that local history is the history of a place or locality whose boundaries are determined by the agreement proposed by the chronicler. Hardiana (2017: 43), in implementing local history into learning, several things must be considered, including the presentation of the material, the learning techniques, and the assessment used. 
Pernantah (2017) wrote that local history has inevitably a strategic function for shaping individual character, fostering national nationalism, and strengthening local and national identities, as well as local history that can pay attention to an independent attitude, full of initiative, and creativity. Not only that, local history that is integrated into learning will also increase students' understanding of an event.

\subsection{Contextual Teaching and Learning}

Contextual teaching and learning defined as a way to introduce learning using active learning methods, which are designed to help students connect what they already know with what is expected to be learned, with the aim of building new knowledge (Hudson, \& Wishler: 2007). Added by Sears (2002), that contextual teaching and learning is a learning concept that helps teachers in linking school learning with real-world situations. Contextual teaching and learning motivates students to take responsibility for their own learning to make connections between knowledge and application.

Learning with contextual teaching and learning (CTL) is a learning system that stimulates the brain to compose patterns that embody meaning. This learning model engages students in important activities that help them relate classroom teaching to the contexts of everyday life they face (Johnson: 2011). The components of contextual teaching and learning include; 1) contructivism, is the idea that in the learning process students will learn independently, find their own interests, and build the knowledge and skills they know and have; 2) inquiry, is an activity that suggests a problem-based learning process. Inquiry learning emphasizes that the knowledge obtained by students is expected not only to come from memorizing information, but also includes findings; 3) questioning, namely developing curiosity in students by asking analytically; 4) learning community, in this component, students are directed to create a learning community from group discussions, where in this activity students will give birth to their own perspective, through a discussion process with various arguments and reasoning and conclusions, debated and discussed, their findings will be tested through the arguments of others; 5) modeling, is a component in CTL that presents a learning model, where with this component students feel close to reality to create an active and contextual learning atmosphere. Learning patterns like this will stimulate the brain to develop and understand information; 6) reflection, by reflecting on the learning material, students will get a learning experience, from this activity, students will gain new knowledge; 7) authentic assessment, invites students to use academic knowledge in a real world context, with the aim of giving meaning and sharpening students' critical thinking skills, analyzing, integrating, identifying problems, making solutions, and following causal relationships (Al Hakim, Sariyatun, \& Sudiyanto. 2018: 177).

Based on the above understanding, it can be concluded that learning with a contextual teaching and learning approach is an approach in learning designed to connect subject matter with students' contextual lives. This learning focuses on the meaning that students can take in the learning process.

\section{Research Methods}

The method used to support this research is a quasi-experimental design with two groups pretest and posttest. The sample used in this is the students of class XI IPA SMAN 03 Gorontalo. The research instrument used was a test to test critical thinking skill which consisted of 6 questions, by adopting Ennis' critical thinking indicators in Costa (1985). The data obtained in this study are quantitative in the form of test scores before and after learning. Data processing in this study used the Statistical Package for Social Science (SPSS) software version 20 with a significance level of $>0.05$. Testing the normality of the data distribution in 
this study was carried out by using the Kolmogorof-Smirnov test, while to see the difference in increasing ability was carried out by using the independent sample test.

\section{Discussion}

To find out an increase in critical thinking skills through local history learning, using a contextual teching and learning approach, first the pre-test and post-test data of students in the control class and experimental class were tested through a series of normality and homogeneity tests. The mean scores obtained by each control and experimental group were 0.200 and 0.116 , meaning that the data were normally distributed, while the results of the homogeneity test obtained were 0.690. This data shows that the two groups have the same initial ability, and meet the requirements to be sampled at the improvement test stage. The critical thinking skills observed in this research can be seen in the following table:

Table.1 Assessed Critical Thinking Skills Aspects and Indicators

\begin{tabular}{|c|c|}
\hline $\begin{array}{c}\text { Critical Thinking Skills } \\
\text { Aspects }\end{array}$ & Critical Thinking Ability Indicator \\
\hline Give a simple explanation & 1. Ask and answer questions that need explanation \\
\hline Build basic skills & $\begin{array}{l}\text { 2. Observe and consider the results of } \\
\text { observations }\end{array}$ \\
\hline Make conclusions & 3. Make and consider the value of the decision \\
\hline Make a further explanation & $\begin{array}{l}\text { 4. Define terms and consider definitions using } \\
\text { appropriate criteria } \\
\text { 5. Identify assumptions }\end{array}$ \\
\hline Devise strategies and tactics & 6. Determine the action \\
\hline
\end{tabular}

Ennis (1985)

The following shows the data on the cognitive test results of the control class and experimental class which were used as research subjects:

Table.2. Statistical Description of the Results of the Cognitive Assessment of the Control Class

\begin{tabular}{|l|l|l|l|l|l|l|l|}
\hline & N & Range & Minimum & Maximum & Mean & $\begin{array}{l}\text { Standard } \\
\text { Deviation }\end{array}$ & Variance \\
\hline $\begin{array}{l}\text { Control class } \\
\text { pretest test results }\end{array}$ & 33 & 40 & 30 & 70 & 49.85 & 9.88 & 92.98851 \\
\hline $\begin{array}{l}\text { The results of the } \\
\text { posttest control } \\
\text { class }\end{array}$ & 33 & 45 & 40 & 85 & 64.84 & 10.79 & 116.38 \\
\hline
\end{tabular}


Table 3. Statistical Description of the Results of the Experimental Class Cognitive Assessment

\begin{tabular}{|l|l|l|l|l|l|l|l|}
\hline & N & Range & Minimum & Maximum & Mean & $\begin{array}{l}\text { Standard } \\
\text { Deviation }\end{array}$ & Variance \\
\hline $\begin{array}{l}\text { The results of } \\
\text { the pretest } \\
\text { experimental } \\
\text { class }\end{array}$ & 33 & 30 & 35 & 65 & 46.36 & 8.77 & 76.98 \\
\hline $\begin{array}{l}\text { The results of } \\
\text { the posttest } \\
\text { experimental } \\
\text { class }\end{array}$ & 33 & 35 & 60 & 95 & 77.88 & 9.85 & 96.92 \\
\hline
\end{tabular}

After obtaining data that the control and experimental groups have the same initial ability, the next step is to find out an increase in critical thinking skills through local history learning with a contextual teaching and learning approach. The improvement test is carried out with the aim of knowing the level of success of local history in improving the quality of history learning and improving students' abilities, especially in analyzing, identifying, evaluating, and synthesizing a historical event. Following are the results of tests conducted to determine the increase in critical thinking skills using the $t$ test, while the aspects assessed include; 1) provide a simple explanation; 2) building basic skills; 3) draw conclusions; 4) Make a further explanation; and 5) developing strategies and tactics.

The hypothesis used:

H0: There is no significant increase and positive effect

H1: There is a significant increase and a positive effect

Decision test:

a) If $\mathrm{t}$ count has a significance level (2 tailed) (>0.05), then $\mathrm{H} 0$ is rejected, and $\mathrm{H} 1$ is accepted

b) If $\mathrm{t}$ count has a significant levelnsi ( 2 tailed) $(<0.05)$, then $\mathrm{H} 0$ is accepted, and $\mathrm{H} 1$ is rejected.

Table.4. Summary of Cognitive Enhancement Tests

\begin{tabular}{|c|c|c|c|c|}
\hline No. & Test Circuit & Type of Test & Sig & Conclusion \\
\hline \multirow[t]{3}{*}{1} & Normality test & \multirow{3}{*}{$\begin{array}{l}\text { Kolmogorov- } \\
\text { Smirnova }\end{array}$} & & \multirow{3}{*}{$\begin{array}{l}\text { Posttest data from the } \\
\text { control class and } \\
\text { experimental class were } \\
\text { normally distributed. }\end{array}$} \\
\hline & Control Class & & $0.200>0.05$ & \\
\hline & Experiment Class & & $0.200>0.05$ & \\
\hline 2 & Homogeneity Test & $\begin{array}{l}\text { Levene } \\
\text { Statistics }\end{array}$ & $0.782>0.05$ & $\begin{array}{l}\text { Posttest data for the } \\
\text { control and } \\
\text { experimental classes } \\
\text { have the same or } \\
\text { homogeneous variants }\end{array}$ \\
\hline \multirow[t]{3}{*}{3} & $\mathrm{~T}$ test & \multirow{3}{*}{$\begin{array}{l}\text { Independent } \\
\text { sample test }\end{array}$} & \multirow[t]{3}{*}{$0.00>0.05$} & \multirow{3}{*}{$\begin{array}{l}\text { There is an increase in } \\
\text { learning outcomes } \\
\text { before and after } \\
\text { treatment }\end{array}$} \\
\hline & Control Class & & & \\
\hline & Experiment Class & & & \\
\hline
\end{tabular}

Following are the results of the test obtained: 
Table 5. Independent Samples Test

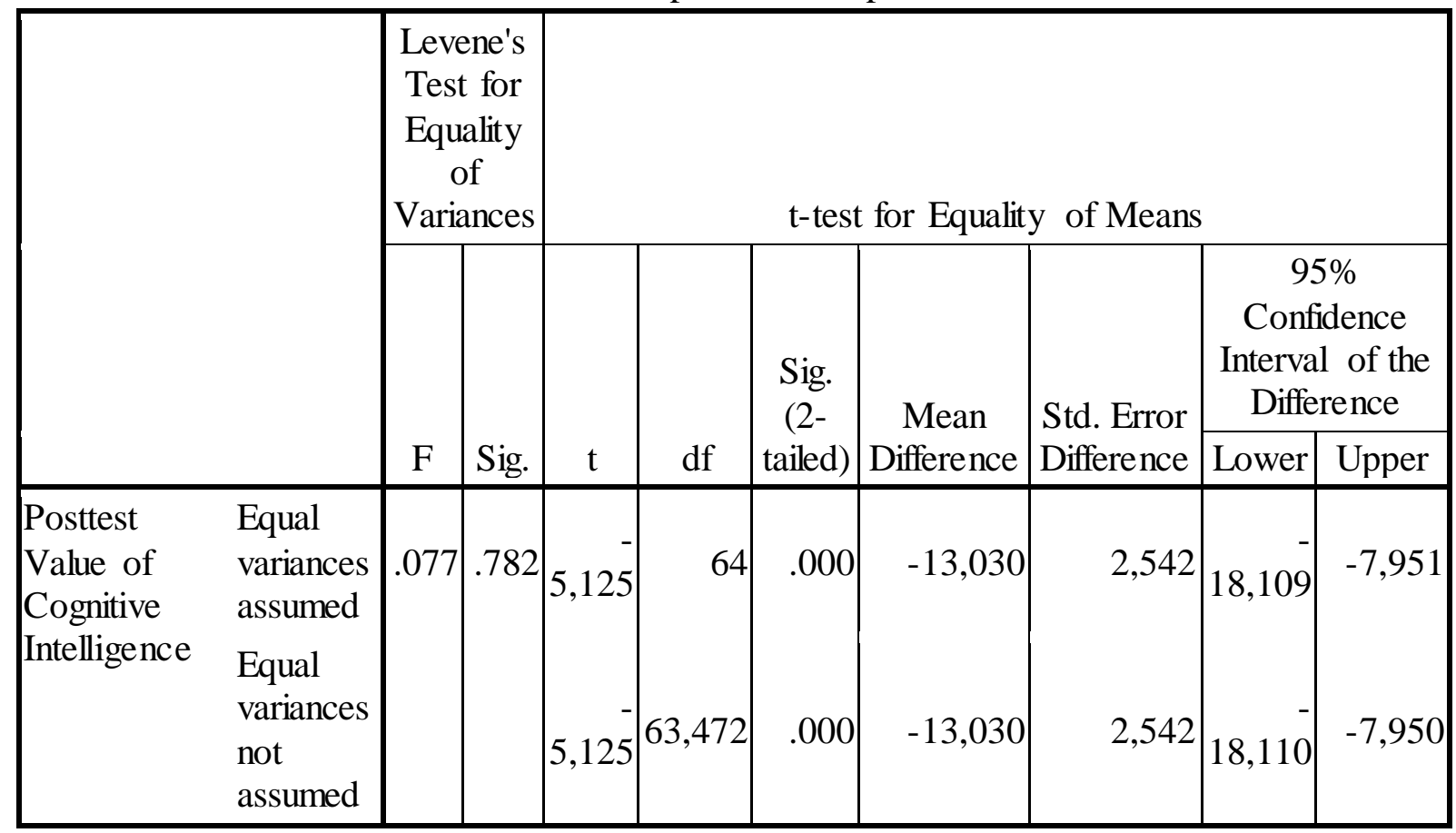

Based on the test results above, it is known that the significance is $0.00<0.05$, it can be concluded that $\mathrm{H} 0$ is rejected and $\mathrm{H} 1$ is accepted. This means that there is an increase in students' critical thinking skills. This increase shows that historical learning integrated with local history using a contextual teaching and learning approach can develop students' cognitive skills, especially in critical thinking skills.

Historical learning with local contentIt can be an alternative for teachers in providing new colors and knowledge for students, as well as an effort to improve students' ability to think critically through local events that can be analyzed and reconstructed. According to Wibowo (2016: 53), the learning process with local history will allow students to get closer to real situations in their environment, bring students to know their surroundings directly, and can break through the boundaries between the school world and the real world of students. Wibowo continued, students will gain a lot of experience, and will be encouraged to develop specific skills, for example by selecting sources, finding facts, and analyzing events. From this statement, we can judge how the learning of history will have meaning if it integrates local elements in it. Learning with local history also has benefits for students in developing a love for local culture and history, and raises enthusiasm in preserving their local identity.

\section{Conclusion}

Based on the findings of research conducted on students at SMAN 03 Gorontalo, it can be concluded that learning history by integrating local history using a contextual teacing and learning approach has been shown to significantly improve students' critical thinking skills. This statement can be proven by a series of tests carried out, where the test obtained a significance of $0.00<0.05$, which means an increase in students' critical thinking skills. This study shows that learning with local history has contributed to improving students' competence in critical thinking skills. 


\section{References}

Al Hakim, Sariyatun, Sudiyanto. (2018). Constructing Students Critical Thingking Through. Discovery Learning Model and Contextual Teaching and Learning Model as Solution of Problems in Learning Hisotory. International Journal of Multicultural and Multireligious Understanding.5 (4).pp.175-183.

Ariati.(2010).Pembelajaran Berbasis Praktikum Untuk Meningkatkan Kemampuan Berpikir Kritis Mahasiswa.

Bailin, Sharon \& Siegel, Harvey. (2002). The Blackwell Guide to the Philosophy of Education.pp.182-193.

Beyer, BK. (1995). Critical Thingking. Bloomington: Phi Delta Kappa Edducational Foundation.

Britt, M,A, J.F Georgi, M.C and Perfetti, C.A.Choirul Machfud.(1994). Learning from History Tests: From Causal Analysis to Argument Model Pendidikan.47-84.

Brooks, Pamela. 2008. How to Research Local History. Oxford: How to Books.

Campbell-Phillips, S. (2020). Education and Curriculum Reform: The Impact They Have on Learning. Budapest International Research and Critics in Linguistics and Education (BirLE) Journal Vol 3 (2): 1074-1082.

Ennis, R.H. (1962). A Concept of Chritical Thinking.Harvard Educational Reviwe. 32(1).pp.81-111.

Ennis, R.H. (1985).Goals for a Critical Thinking I Curiculum. Developing Minds A Resource Book for Teaching Thingking.Virginia: Asscociation for Suopervisions and Curriculum Development (ASCD).

Ennis, R.H. (2009).Critical Thingking Assessment.pp.179-186.

Hardiana. (2017). Pembelajaran Sejarah Indonesia Berbasis Peristiwa-Peristiwa Lokal di Tasikmalaya Untuk Meningkatkan Kemampuan Berpikir Kritis. Journal of Historia.1 (1).pp.41-45.

Hudsno, Charles \& Wishler, Vesta.(2007).Contextual Teaching and Learning for Practitioners.

Johnson, E.(2006).Contextual Teaching and Learning. Bandung : MLC.

Langbein, L.I, Litjman A.J.(1978).Ecological Inference.Sage Publication.

Mulyana, Agus \& Restu, Gunawan. (2007) .Sejarah Lokal dalam Penulisan dan Pembelajaran di Sekolah.Bandung : Salamina.

Pernantah, Piki Setri.(2017). Membangun Wawasan Sejarah Lokal Si.swa dengan Penguatan Scaffolding dalam Pembelajaran Sejarah.7.1.pp.46-58.

Redecker, C., Ala-Mutka, K., Leis, M., Leendertse, M., Punie, Y., Gijsbers, G., Kirschner, P., Stoyanov, S. and Hoogveld, B. 2011. The Future of Learning: Preparing for Change. Luxembourg : Publications Office of the European Union.

Rizqi, Y.F., Djono, and Susanto. (2020). Development of Local History Learning with the Heroism Theme of K. Gholib Based on E-Book for Private Vocational School Students in Pringsewu Regency. Budapest International Research and Critics in Linguistics and Education (BirLE) Journal Vol 3 (3): 1287-1300.

Rosmiati, Wahyuni, A., and Syarifuddin, A. (2020). Ombilin Coal Mine Site: History and Potential as a Learning Source for the History of the Economy Based on Outdoor Learning. Budapest International Research and Critics in Linguistics and Education (BirLE) Journal Vol 3 (3): 1343-1352.

Sears, J.S.(2003). Introduction to Contextual Teaching and Learning.Phi Delta Kappa Educational Foundation. 
Supardan, Dadang. (2004). Kesadaran Sejarah Berbasis Pendekatan Multikultural dan Perspektif Sejarah Lokal, Nasional, Global dalam Integrasi Bangsa.Disertasi, Bandung: PPS UPI.

Subakti, Y.R. (2010). Paradigma Pembelajaran Sejarah Berbasis Konstruktivisme Vol.24.Nol.

Wibowo, A.M.2016. Pengembangan Model Pembelajaran Sejarah Lokal di SMA Kota Madiun.Volume.6.No.1.pp.46-57. 